\title{
Mitigation of methane emissions in a pilot-scale biocover system at the AV Miljø Landfill, Denmark: 2. Methane oxidation
}

\author{
Scheutz, Charlotte; Cassini, Filippo; De Schoenmaeker, Jan; Kjeldsen, Peter
}

Published in:

Waste Management

Link to article, DOI:

10.1016/j.wasman.2017.01.012

Publication date:

2017

Document Version

Peer reviewed version

Link back to DTU Orbit

Citation (APA):

Scheutz, C., Cassini, F., De Schoenmaeker, J., \& Kjeldsen, P. (2017). Mitigation of methane emissions in a pilotscale biocover system at the AV Miljø Landfill, Denmark: 2. Methane oxidation. Waste Management, 63, 203212. https://doi.org/10.1016/j.wasman.2017.01.012

\section{General rights}

Copyright and moral rights for the publications made accessible in the public portal are retained by the authors and/or other copyright owners and it is a condition of accessing publications that users recognise and abide by the legal requirements associated with these rights.

- Users may download and print one copy of any publication from the public portal for the purpose of private study or research.

- You may not further distribute the material or use it for any profit-making activity or commercial gain

- You may freely distribute the URL identifying the publication in the public portal 
Mitigation of methane emissions in a pilot-scale biocover system at the AV Miljø Landfill, Denmark: 2. Methane oxidation

Charlotte Scheutz, Filippo Cassini, Jan De Schoenmaeker, Peter Kjeldsen

Department of Environmental Engineering, Technical University of Denmark, DK-2800 Kgs. Lyngby, Denmark

\section{ABSTRACT}

Greenhouse gas mitigation at landfills by methane $\left(\mathrm{CH}_{4}\right)$ oxidation in engineered biocover systems is believed to be a cost effective technology but so far a full quantitative evaluation of the efficiency of the technology in full scale has only been carried out in a few cases. A third generation semi-passive biocover system was constructed at the AV Miljø Landfill, Denmark. The biocover was fed by landfill gas pumped out of three leachate collection wells. An innovative gas distribution system was used to overcome the often observed uneven gas distribution to the active $\mathrm{CH}_{4}$ oxidation layer resulting in overloaded areas causing $\mathrm{CH}_{4}$ emission hot spot areas in the biocover surface. The whole biocover $\mathrm{CH}_{4}$ oxidation efficiency was determined by measuring the $\mathrm{CH}_{4}$ inlet load and $\mathrm{CH}_{4}$ surface fluxes. In addition, $\mathrm{CH}_{4}$ oxidation was determined for single points in the biocover using two different methods; the carbon mass balance method (based on $\mathrm{CH}_{4}$ and carbon dioxide $\left(\mathrm{CO}_{2}\right)$ concentrations in the deeper part of the cover and $\mathrm{CH}_{4}$ and $\mathrm{CO}_{2}$ surface flux measurements) and a new-developed tracer gas mass balance method (based on $\mathrm{CH}_{4}$ and tracer inlet fluxes and $\mathrm{CH}_{4}$ and tracer surface flux measurements). Overall, the $\mathrm{CH}_{4}$ oxidation efficiency of the whole biocover varied between 81 and $100 \%$ and showed that the pilot plant biocover system installed at AV Miljø landfill was very efficient in oxidizing the landfill $\mathrm{CH}_{4}$. The average $\mathrm{CH}_{4}$ oxidation rate measured at nine campaigns was approximately $13 \mathrm{~g} \mathrm{~m}^{-2} \mathrm{~d}^{-1}$. Extrapolating laboratory measured $\mathrm{CH}_{4}$ oxidation rates to the field showed that the biocover system had a much larger $\mathrm{CH}_{4}$ oxidation potential in comparison to the tested $\mathrm{CH}_{4}$ load. The carbon mass balance approach compared reasonably well with the tracer gas mass balance approach when applied for quantification of $\mathrm{CH}_{4}$ oxidation in single points at the biofilter giving $\mathrm{CH}_{4}$ oxidation efficiencies in the range of 84 to a $100 \%$. $\mathrm{CH}_{4}$ oxidation rates where however much higher using the tracer gas balance method giving $\mathrm{CH}_{4}$ oxidation rates between 7 and $124 \mathrm{~g} \mathrm{~m}^{2} \mathrm{~d}^{-1}$ compared to the 
carbon mass balance, which gave $\mathrm{CH}_{4}$ oxidation rates -0.06 and $40 \mathrm{~g} \mathrm{~m}^{2} \mathrm{~d}^{-1}$. The study also revealed that the compost respiration contributed significantly to the measured $\mathrm{CO}_{2}$ surface emission, and that the contribution of the compost respiration decreased significantly with time probably due to further maturation of the compost material.

Keywords: greenhouse gas, waste disposal, mitigation documentation, engineered solutions

\section{Introduction}

Landfills contain organic waste, which leads to production of biogas containing methane $\left(\mathrm{CH}_{4}\right)$ and carbon dioxide $\left(\mathrm{CO}_{2}\right)$. Landfills are important sources of atmospheric $\mathrm{CH}_{4}$, which contributes to climate change (Bogner et al., 2008). At some landfills utilization of landfill gas (LFG) is not or cannot be carried out, and the gas is either flared with risk of producing toxic combustion products or just emitted to atmosphere. As an alternative to mitigation by gas utilization systems, mitigation systems based on $\mathrm{CH}_{4}$ oxidation processes may be implemented. Such systems, here called biocover systems are based on microbial $\mathrm{CH}_{4}$ oxidation in full surface biological biocovers, biowindow systems or open or closed bed biofilter systems. Experiments have documented that very high $\mathrm{CH}_{4}$ oxidation rates can be obtained in bio-covers, high enough to significantly reduce $\mathrm{CH}_{4}$ emissions from landfills (Scheutz et al., 2009). Documentation of the efficiency of bio-covers has so far only been carried out in full scale in a few cases for example in a research project carried out at Fakse Landfill where a new-developed protocol for biocover establishment and monitoring were presented (Scheutz et al., 2011a, b) and in a project where a second generation biocover system was established at the Klintholm Landfill (Scheutz et al., 2014, Kjeldsen et al., 2009). Both of the mentioned biocover systems were passively loaded with landfill gas from the landfilled waste.

This study was carried out at AV Miljø, which is a modern landfill situated outside Copenhagen, Denmark. The landfill receives non-combustible waste with a low organic content. $\mathrm{CH}_{4}$ is produced but in too little quantities for energy utilization. The LFG produced at the landfill is mainly emitting through the leachate collection wells. More details of the landfill are given in Scheutz et al. (2011c). A semi-passive pilot-scale compost based biocover system designed for $\mathrm{CH}_{4}$ oxidation was installed in September 2012 at the AV Miljø 
Landfill with the aim to mitigate $\mathrm{CH}_{4}$ emissions from the landfill. The biocover system (12 $\left.\mathrm{m} \times 42 \mathrm{~m}\right)$ consisted of a gas distribution layer $(30-50 \mathrm{~cm})$ overlain by a compost layer $(80-90 \mathrm{~cm})$. The $\mathrm{CH}_{4}$ fed to the biocover was collected from three leachate wells. Inlet pumping rates and $\mathrm{CH}_{4}$ contents were continuously monitored. Other gases (oxygen $\left(\mathrm{O}_{2}\right)$, carbon dioxide $\left(\mathrm{CO}_{2}\right)$ and nitrogen $\left(\mathrm{N}_{2}\right)$ ) were monitored manually on a monthly basis. A pipe system consisting of a combination of un-slotted and slotted pipes was used to feed and homogenously distribute the LFG to the compost layer. The upper surface of the gravel gas distribution layer was shaped in a series of valley and ridges (in a "zig zag" shape) to minimize continuous water accumulation in the compost layer and subsequent locking due to capillary effects. The biocover system was equipped with a water draining system including a water lock to avoid gas by-pass. A section of the gas distribution layer and the compost layer was equipped with horizontal multi-port gas monitoring units to study gas distribution and $\mathrm{CH}_{4}$ oxidation processes. Two transects each having 50 gas ports were constructed at two different distances from the gas inlet. More details of the biocover system design are given in Cassini et al. (2017).

The objective of this study was to quantify the efficiency of $\mathrm{CH}_{4}$ oxidation in the biocover system using several approaches. The $\mathrm{CH}_{4}$ oxidation efficiency was determined for single points in the biocover using two methods: a) Carbon mass balances (based on $\mathrm{CH}_{4}$ and $\mathrm{CO}_{2}$ concentrations in the deeper part of the cover and $\mathrm{CH}_{4}$ and $\mathrm{CO}_{2}$ surface flux measurements), and b) Tracer gas mass balances (based on $\mathrm{CH}_{4}$ and tracer inlet fluxes and $\mathrm{CH}_{4}$ and tracer surface flux measurements). A potential inhibitory effect from the presence of the tracer to the $\mathrm{CH}_{4}$ oxidation process was evaluated in laboratory batch experiments. The $\mathrm{CH}_{4}$ oxidation efficiency of the whole biocover was evaluated by establishment of a $\mathrm{CH}_{4}$ mass balance for the biocover system (based on $\mathrm{CH}_{4}$ inlet load and $\mathrm{CH}_{4}$ surface flux measurements). Due to elevated temperatures in the biocover as a result of $\mathrm{CH}_{4}$ oxidation and compost respiration processes, the field based $\mathrm{CH}_{4}$ oxidation efficiency of the whole biocover was supported by laboratory batch experiments to study the temperature dependency of the $\mathrm{CH}_{4}$ oxidation and compost respiration processes.

This paper is the second in a series of two. The first paper presents the design of the biocover system and investigations on the gas distribution in the biocover system (Cassini et al., 2017).

\section{Materials \& Methods}




\subsection{Laboratory experiments: Methane oxidation and respiration}

Two batch laboratory experiments were carried out during the biocover study to evaluate compost respiration, $\mathrm{CH}_{4}$ oxidation capacity, and the potential inhibitory effect from the added tracer gas $(1,1,1,2-$ Tetrafluoroethane $\left(\mathrm{C}_{2} \mathrm{H}_{2} \mathrm{~F}_{4}\right)$ commercially referred to as $\left.\mathrm{HFC}-134 \mathrm{a}\right)$ toward the microbial $\mathrm{CH}_{4}$ oxidation process (see next section). Biocover compost was sampled at two different locations of the biocover in November 2012 and April 2013, respectively. The two locations were chosen randomly to represent different parts of the biocover. At both occasions, samples were taken at different depths of the biocover using an auger and immediately sealed in tight plastic bags to avoid moisture evaporation. Sample locations are shown in Fig. 1. The first compost sample was taken close to $\mathrm{T} 2$ and used for the compost $\mathrm{CH}_{4}$ oxidation and respiration test, while the later sample was taken at 5.2 and used for the tracer inhibition test. Two types of compost samples were used for the study: compost from a specific depth $(-40 \mathrm{~cm}$ depth) and composite compost sample, obtained by manually mixing compost samples from different depths. The first composite sample consisted of a mix of compost from five depths $(-20 \mathrm{~cm},-40 \mathrm{~cm},-60 \mathrm{~cm},-80 \mathrm{~cm},-90 \mathrm{~cm})$, whereas the second composite sample consisted of compost from three depths $(-20 \mathrm{~cm},-40 \mathrm{~cm},-60 \mathrm{~cm})$. The sampling depth of $40 \mathrm{~cm}$ was chosen as gas concentration profiles and temperature measurements in the biocover indicated optimal conditions for $\mathrm{CH}_{4}$ oxidation at this depth (see section 3.3 and Cassini et al., 2017).

For all batch experiments a standard experimental setup was used. Standard glass bottles $(500 \mathrm{~mL})$ were filled with $50 \mathrm{~g}$ of moist compost, previously sieved to avoid inhomogeneities. The bottles were sealed with gas tight butyl rubber septa (Norsorex DC 97 rubber stoppers) and aluminum caps. Bottles intended for $\mathrm{CH}_{4}$ oxidation capacity evaluation were pre-treated overnight by injecting $80 \mathrm{~mL}$ of pure $\mathrm{CH}_{4}$ to activate methanotrophic bacteria naturally present in the compost. This normally reduces lag phases and thus maximal $\mathrm{CH}_{4}$ oxidation rates can be calculated using the initial $\mathrm{CH}_{4}$ concentration and time. Bottles were reopened and flushed with air to remove remaining $\mathrm{CH}_{4}$ and $\mathrm{CO}_{2}$. After the final sealing, gas was extracted from the bottles ( $120 \mathrm{~mL}$ for respiration bottles and $200 \mathrm{~mL}$ for $\mathrm{CH}_{4}$ oxidation bottles) and replaced with pure gases to create suitable conditions for microbial reactions. A starting $\mathrm{O}_{2}$ concentration of about $30 \%$ vol. (120 $\mathrm{mL}$ ) was chosen for compost respiration evaluation. Starting concentrations in bottles for $\mathrm{CH}_{4}$ oxidation evaluation were $12-14 \%$ vol. ( $80 \mathrm{~mL}$ ) for $\mathrm{CH}_{4}$ and $32-35 \%$ vol. $\left(120 \mathrm{~mL}\right.$ ) for $\mathrm{O}_{2}$. The initial high $\mathrm{O}_{2}$ content should assure sufficient $\mathrm{O}_{2}$ for both $\mathrm{CH}_{4}$ oxidation and compost respiration. Gas samples were transferred 
every 12 hours from the bottles to standard vacuum $5 \mathrm{~mL}$ Exetainers $\odot$ (Vial $819 \mathrm{~W}, 6 \mathrm{~mL}$, Labco Ltd., UK) by using gas tight syringes. Gas samples composition $\left(\mathrm{O}_{2}, \mathrm{CO}_{2}\right.$ and $\mathrm{CH}_{4}$ concentrations) were analyzed by using a gas chromatograph (Agilent Technologies MicroGC 490). Calibration was performed using laboratory standard gas mixtures ranging from 1 to $40 \%$ vol. As the Exetainers $\odot$ are not completely vacuumed ( $5 \mathrm{~mL}$ vacuumed volume out of $6 \mathrm{~mL}$ total volume), the standard gas mixtures were injected $(5 \mathrm{~mL})$ into Exetainers $\odot$ prior to analysis. Measured concentrations were plotted with time and generation or consumption rates of gases calculated $\left(\mathrm{O}_{2}\right.$ and $\mathrm{CO}_{2}$ for respiration test, $\mathrm{CH}_{4}$ and $\mathrm{CO}_{2}$ for $\mathrm{CH}_{4}$ oxidation). Maximum generation or consumption rates were determined by applying a zero order kinetic to the data for the initial phase of the test period. Compost moisture contents were separately measured and generation or consumption rates normalized to dry mass (DM). For all experiments duplicates and blanks (bottles with injected gases but without compost addition) were incubated to check for potential gas loss during the experimental run.

The $\mathrm{CH}_{4}$ oxidation batch test series was started in November 2012 and had a duration of about 100 hours, while the respiration test was started in December 2012 and had a duration of 350 hours. In both experiments a composite compost sample (obtained by mixing equal amounts of compost from all sampled depths; $-20 \mathrm{~cm},-40 \mathrm{~cm},-60 \mathrm{~cm},-80 \mathrm{~cm},-90 \mathrm{~cm})$ were incubated at eight different temperatures $\left(4^{\circ} \mathrm{C}, 10^{\circ} \mathrm{C}\right.$, $15^{\circ} \mathrm{C}, 20^{\circ} \mathrm{C}, 30^{\circ} \mathrm{C}, 40^{\circ} \mathrm{C}, 55^{\circ} \mathrm{C}, 70^{\circ} \mathrm{C}$ ) with the purpose of analyzing the temperature dependence of $\mathrm{CH}_{4}$ oxidation and respiration of a standard compost sample. The tested temperature range was comparable to the temperature range measured in the biocover $\left(3\right.$ to $\left.60^{\circ} \mathrm{C}\right)$ (Cassini et al., 2017). The moisture content on the incubated compost sample was $0.4 \mathrm{~g} \mathrm{~g} \mathrm{DM}^{-1}$, thus the samples were sufficiently moist, so moisture was not limiting $\mathrm{CH}_{4}$ oxidation and temperature was the main controlling factor.

\subsection{Laboratory experiments for tracer influence evaluation on methanotrophic oxidation}

A tracer gas (HFC-134a) was injected during several measuring campaigns performed at AV Miljø biocover to calculate the $\mathrm{CH}_{4}$ oxidation efficiency of the bacterial community (see section 2.4) and to study the gas distribution quality of the system (confer Cassini et al., 2017 for more details on the tracer experiment and gas distribution quality). In order to study the possible inhibitory effect of the tracer gas on the microbial methane oxidation activity, two laboratory experiments were carried out. The compost was sampled in April 2013 at location 5.2 (see Figure 4.1). For both experiments compost were sampled from the biocover at three depths $(-20 \mathrm{~cm},-40 \mathrm{~cm}$ and $-60 \mathrm{~cm})$. Two compost samples were then prepared; a 
compost sampled from $-40 \mathrm{~cm}$ depth and a composite compost sample consisting of an equal mix of compost from $-20 \mathrm{~cm},-40 \mathrm{~cm}$ and $-60 \mathrm{~cm}$ depth. For both experiments, standard bottles $(500 \mathrm{~mL})$ were filled with $50 \mathrm{~g}$ sieved compost and sealed with butyl rubber septa and aluminum caps as in the batch tests described in the previous section (section 2.2). The compost in the bottles was pre-treated for 12 hours with $80 \mathrm{~mL}$ of $\mathrm{CH}_{4}$ to shorten bacterial lag phase; bottles were then flushed with air before the experimental procedure started. The same experimental procedure as described in the previous section was adopted.

The first tracer batch test had a duration of about 130 hours. The purpose of this experiment was to evaluate the eventual potential inhibitory effect of HFC-134a gas on the microbial methane oxidation activity as a function of HFC-134a concentration. The compost sample from $40 \mathrm{~cm}$ depth was chosen to represent compost where significant $\mathrm{CH}_{4}$ oxidation had been observed. The compost was incubated at $50^{\circ} \mathrm{C}$, which was a typical temperature observed in the biocover at $40 \mathrm{~cm}$ depth (see Cassini et al., 2017). Air was extracted from the sealed bottle $(200 \mathrm{~mL})$ and replaced with $80 \mathrm{~mL}$ of $\mathrm{CH}_{4}$ and $120 \mathrm{~mL}$ of $\mathrm{O}_{2}$ as previously done for the $\mathrm{CH}_{4}$ oxidation batch tests. Five different quantities of tracer (HFC-134a) were then injected into the bottles creating five increasing mixing ratios ( 0 ppmv, 8 ppmv, 40 ppmv, 90 ppmv and 140 ppmv). The highest tracer mixing ratio was well above the maximum field tracer gas mixing ratio of about 80 ppmv.

To confirm the findings of the first tracer gas inhibition test for other compost depths and temperatures, the second tracer gas batch test was carried out on both the compost sample from $40 \mathrm{~cm}$ depth and on the mixed compost sample. The compost was incubated at two temperatures $\left(30^{\circ} \mathrm{C}\right.$ and $\left.50^{\circ} \mathrm{C}\right)$. The initial $\mathrm{CH}_{4}$ concentration was between 14 and $18 \%$ vol., while the initial tracer gas concentration was 160 ppmv. To conclude on any potential inhibitory effect on the methane oxidation activity, only half of the batches received tracer gas. For both tests, duplicates and blanks were prepared for most combinations. The moisture content on the incubated compost sample was $0.4 \mathrm{~g} \mathrm{~g} \mathrm{DM}^{-1}$, thus the samples were sufficiently moist, so moisture was not limiting $\mathrm{CH}_{4}$ oxidation.

\subsection{Determination of in-situ single point $\mathrm{CH}_{4}$ oxidation by the carbon mass balance method}

The $\mathrm{CH}_{4}$ oxidation in a single point of the biocover can be determined by establishment of a carbon mass balance for that specific point. The carbon mass balance method is described in Christophersen et al. (2001), Einola et al. (2008), Philopoulos et al. (2008), Einola et al. (2009) and more recently in Pedersen et al. (2011). The method builds on the conservation of mass for carbon and assumes that the relationship 
between the fluxes of $\mathrm{CH}_{4}$ and $\mathrm{CO}_{2}$ and the concentrations of $\mathrm{CH}_{4}$ and $\mathrm{CO}_{2}$ is equal in the bottom of the compost cover and that the vertical gas flow is uniform in the region of the sampling point. The method is based on the assumption of steady state and therefore assimilation of carbon by the methanotrophic bacteria is not accounted for (it is thus assumed that growth equals decay). Additionally, the dilution of $\mathrm{CO}_{2}$ in percolating rainwater was assumed negligible, as was found in Christophersen et al., (2001). Finally, we did not consider $\mathrm{CO}_{2}$ production from compost respiration. Combining Eq. 1 and 2 results in Eq. 3, which was used to calculate the load of $\mathrm{CH}_{4}$ entering the biocover in a specific point. Eq. 4 was used to calculate the

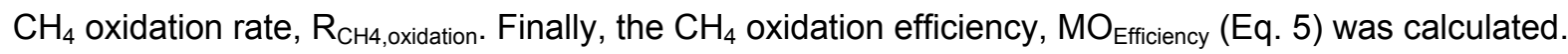

$J_{L F G, \text { bottom }}=J_{\mathrm{CO}_{2}, \text { surface }}+J_{\mathrm{CH}_{4} \text {, surface }}=J_{\mathrm{CO}_{2}, \text { bottom }}+J_{\mathrm{CH}_{4}, \text { botttom }}$

$\frac{J_{\mathrm{CH}_{4}, \text { bottom }}}{J_{\mathrm{CH}_{4}, \text { bottom }}+J_{\mathrm{CO}_{2}, \text { bottom }}}=\frac{C_{\mathrm{CH}_{4}, \text { bottom }}}{C_{\mathrm{CH}_{4}, \text { bottom }}+C_{\mathrm{CO}_{2}, \text { bottom }}}$

$J_{\mathrm{CH}_{4} \text {, bottom }}=\frac{\mathrm{C}_{\mathrm{CH}_{4}, \text { bottom }}}{C_{\mathrm{CH}_{4}, \text { bottom }}-C_{\mathrm{CO}_{2}, \text { bottom }}} \cdot\left(J_{\mathrm{CO}_{2}, \text { surface }}+J_{\mathrm{CH}_{4} \text {, surface }}\right)$

$R_{\mathrm{CH}_{4} \text { oxidation }}=J_{\mathrm{CH}_{4}, \text { bottom }}-J_{\mathrm{CH}_{4} \text {, surface }}$

$M O_{\text {Efficiency }}=100 \cdot \frac{J_{\mathrm{CH}_{4}, \text { bottom }}-J_{\mathrm{CH}_{4} \text {, surface }}}{J_{\mathrm{CH}_{4}, \text { bottom }}}$

$J_{L F G, \text { bottom }}$ is the load of landfill gas coming into the biocover, $J_{C O 2 \text {, surface }}$ is the surface $\mathrm{CO}_{2}$ emission, and $J_{C H 4, \text { surface }}$ is the surface $\mathrm{CH}_{4}$ emission. $\mathrm{C}_{\mathrm{CH} \text {,bottom }}$ and $\mathrm{C}_{\mathrm{CO} \text {,bottom }}$ are the concentrations of $\mathrm{CH}_{4}$ and $\mathrm{CO}_{2}$ in the bottom of the biocover. $J_{C H 4, \text { bottom }}$ is the load of $\mathrm{CH}_{4}$ into the biocover and $R_{C H 4 o x i d a t i o n}$ is the $\mathrm{CH}_{4}$ oxidation rate.

To quantify the $\mathrm{CH}_{4}$ oxidation efficiency at specific points in the biocover, gas concentrations of $\mathrm{CH}_{4}$ and $\mathrm{CO}_{2}$ at $-95 \mathrm{~cm}$ depth in the biocover were determined in parallel with measuring surface fluxes of $\mathrm{CH}_{4}$ and $\mathrm{CO}_{2}$. Two field campaigns were carried out between November 2012 and January 2013 and included eight measuring points in the cover ( $\mathrm{S} 1, \mathrm{~S} 7-8, \mathrm{~S} 10, \mathrm{~N} 1, \mathrm{~N} 7-8$, and $\mathrm{N} 10)$. The surface flux chambers as well as the horizontal multi-port gas probe sampling system is described in details in Cassini et al. (2017). Each flux chamber was placed on the surface covering the same area as where the probes for gas concentration sampling were situated (the 8 sampling locations are shown in Fig. 1 as S1, S7-8, S10, N1, N7-8, and N10). 


\subsection{Determination of single point in-situ $\mathrm{CH}_{4}$ oxidation by the tracer mass balance method}

A new and innovative method for quantifying $\mathrm{CH}_{4}$ oxidation was tested using the injection of an inert gas inside the biocover body. The inert gas, called tracer gas, was mixed into the inlet flow of LFG. Tracer gas inlet flow and surface fluxes in single points were measured (see Cassini et al., 2017). The tracer gas mass balance is based on the assumptions that the tracer gas is not subjected to production or consumption and that steady state of the tracer gas movement in the biocover has been reached. The $\mathrm{CH}_{4}$ oxidation efficiency, $\mathrm{MO}_{\text {Efficiency }}$ can be determined by measuring the $\mathrm{CH}_{4}$ to trace gas flux ratio in the inlet and at the biocover surface using equation 6 . It is noticed that the assumption of vertical 1-D flow set up for the carbon mass balance method is not needed for the tracer mass balance method.

$M O_{\text {Efficiency }}=\frac{\left(\frac{J_{\mathrm{CH}_{4}}}{J_{\text {tracegas }}}\right)_{\text {Inlet }}-\left(\frac{J_{\mathrm{CH}_{4}}}{J_{\text {tracegas }}}\right)_{\text {Surface }}}{\left(\frac{J_{\mathrm{CH}_{4}}}{J_{\text {tracegas }}}\right)_{\text {Inlet }}}$

The tracer gas was continuously pumped at a controlled rate into the inlet mixing chamber and further distributed to the gas distribution layer and the $\mathrm{CH}_{4}$ oxidation layer (confer Cassini et al. ( 2017) for more details on the performance of the tracer test). Tracer gas breakthrough curves in selected points of the horizontal multi-port gas probe sampling units were established by sampling and analyzing the tracer gas concentration over time in the duration of the tracer gas experiment. At the end of the tracer gas experiment, tracer gas emissions through the surface of the biocover was measured in 50 locations by use of a mobile static flux chamber (confer Cassini et al., 2017). A complete tracer gas mass balance (total influx of tracer gas equaled total surface flux of tracer gas) showed that steady state conditions were obtained at this point in time (Cassini et al., 2017). The $\mathrm{CH}_{4}$ oxidation of the biocover was then determined by calculating the ratio of $\mathrm{CH}_{4}$ to tracer gas surface fluxes in selected points and comparing these to the ratio of the inlet $\mathrm{CH}_{4}$ to tracer gas flux (in accordance to Eq. 6). 


\subsection{Determination of whole biocover $\mathrm{CH}_{4}$ oxidation based on $\mathrm{CH}_{4}$ load and $\mathrm{CH}_{4}$ surface emission}

The whole biocover $\mathrm{CH}_{4}$ oxidation efficiency was determined by comparing the measured $\mathrm{CH}_{4}$ inlet load to the biocover with the integrated $\mathrm{CH}_{4}$ surface emission from the biocover. $\mathrm{The} \mathrm{CH}_{4}$ load to the biocover was continuously monitored and surface emissions of $\mathrm{CH}_{4}$ and $\mathrm{CO}_{2}$ were measured using stationary flux chambers (both activities are described in Cassini et al. (2017)). The total $\mathrm{CH}_{4}$ emission from the biocover was determined by kriging interpolation of the measured surface fluxes (see Cassini et al. 2017). In total, nine campaigns were conducted in the period from January 2013 to March 2014. At each campaign, the surface fluxes were measured in 50 locations in the biocover.

A tracer gas test was performed in the period May $16^{\text {th }}-27^{\text {th }}, 2013$ where tracer gas was mixed into the inlet gas fed the biocover. At the end of the tracer gas test (on May $24^{\text {th }}, 2013$ ) tracer gas and $\mathrm{CH}_{4}$ surface fluxes were measured in 50 locations in the biocover (Cassini et al. 2017). The $\mathrm{CH}_{4}$ oxidation of the biocover was then determined following the approach explained in section 2.4 using Eq. 6 comparing the ratio of $\mathrm{CH}_{4}$ to tracer gas in the inlet to the surface flux ratio. However, instead of determining the $\mathrm{CH}_{4}$ oxidation in individual points, the surface flux $\mathrm{CH}_{4}$ to tracer gas ratio was obtained by kriging interpolation of the measured surface fluxes of $\mathrm{CH}_{4}$ and tracer gas (in the 50 locations) and thus the $\mathrm{CH}_{4}$ oxidation of the whole cover was determined.

\section{Results \& Discussion}

\subsection{Methane oxidation and respiration of compost material}

Table 1 shows the results of methane oxidation and respiration experiments performed at different temperatures on the composite compost sample from November 2012. The highest $\mathrm{CH}_{4}$ oxidation rate $(73$ $\mu \mathrm{g} \mathrm{CH} \mathrm{gDM}^{-1} \mathrm{~h}^{-1}$ ) was obtained at $55^{\circ} \mathrm{C}$. At $70^{\circ} \mathrm{C}$, the $\mathrm{CH}_{4}$ oxidation was significantly reduced (to $2.0 \mu \mathrm{g} \mathrm{CH}_{4}$ $\mathrm{gDM}^{-1} \mathrm{~h}^{-1}$ ) indicating an optimum temperature of $55^{\circ} \mathrm{C}$ or higher but below $70^{\circ} \mathrm{C}$, which is higher than what was found at a previous study of compost sampled from the Klintholm Biocover (Scheutz et al., 2011d) where an optimal temperature of $45^{\circ} \mathrm{C}$ was observed. The high optimum temperature indicates presence of thermotolerant and/or thermophilic methanotrophs, which could be elucidated by performance of microbial analysis. Observed optimum temperature at $45-55^{\circ} \mathrm{C}$ is much higher than what is often reported for landfill cover soils (Scheutz et al., 2009). 
Data from the compost respiration experiments showed a substantial $\mathrm{O}_{2}$ consumption and simultaneous $\mathrm{CO}_{2}$ generation activity in the biocover compost. Both the $\mathrm{O}_{2}$ consumption and the $\mathrm{CO}_{2}$ generation clearly increased when the temperature was increased. In the temperature range of 4 to $70^{\circ} \mathrm{C}$, the $\mathrm{O}_{2}$ consumption ranged between 1.1 and $65 \mu \mathrm{g} \mathrm{O}_{2} \mathrm{gDM}^{-1} \mathrm{~h}^{-1}$, whereas the $\mathrm{CO}_{2}$ production ranged between 0.5 and $73 \mu \mathrm{g} \mathrm{CO}_{2} \mathrm{gDM}^{-1} \mathrm{~h}^{-1}$, with maximum rates obtained at a temperature of $70^{\circ} \mathrm{C}$ (Table 1). The respiration experiment thus showed that an optimal temperature was not reached as the highest $\mathrm{O}_{2}$ consumption and $\mathrm{CO}_{2}$ production was seen in the batches with the highest applied incubation temperature $\left(70^{\circ} \mathrm{C}\right)$. This is probably not surprising since high temperatures $\left(>70^{\circ} \mathrm{C}\right)$ are observed in composting windrows (e.g. Andersen et al., 2010). Composting is a self-driven process as it is exothermic and it will thus perform better at higher temperatures.

Table 2 shows additional results regarding $\mathrm{CH}_{4}$ oxidation rates from batch experiments, but achieved on compost samples collected in the biocover six months later (April 2013) and at another location (5.2). $\mathrm{CH}_{4}$ oxidation rates for experiments performed at $50^{\circ} \mathrm{C}$ were in the same range (57 to $79 \mu \mathrm{g} \mathrm{CH}_{4} \mathrm{gDM}^{-1} \mathrm{~h}^{-1}$ ) as the first incubation experiments. However, for experiments carried out at $30^{\circ} \mathrm{C}$ consistently higher $\mathrm{CH}_{4}$ oxidation rates were observed for the April sample compared to the November sample, $\left(131 \mu \mathrm{g} \mathrm{CH}_{4} \mathrm{gDM}^{-1}\right.$ $\mathrm{h}^{-1}$ compared to about $25 \mu \mathrm{g} \mathrm{CH} \mathrm{gDM}^{-1} \mathrm{~h}^{-1}$ ). Thus there seems to be different temperature optimums depending on sample location and/or time of sampling. Factors that could explain the different $\mathrm{CH}_{4}$ oxidation rate observed at the two sampling locations ( $\mathrm{T} 2$ and 5.2) include temperature and moisture differences in the biocover, and $\mathrm{CH}_{4}$ exposure differences in terms of both $\mathrm{CH}_{4}$ load to the oxidation layer and pre-exposure time (compost was sampled with about 5 months apart). No considerable difference could be observed between the $\mathrm{CH}_{4}$ oxidation capacity of compost from a particular depth $(-40 \mathrm{~cm})$ and the composite compost sample made out of compost from different depths (Table 2) indicating a broader zone (from -20 to $-60 \mathrm{~cm}$ ) in the biocover with methanotrophic activity.

A wide range of $\mathrm{CH}_{4}$ oxidation rates have been reported in a previous study (Scheutz et al., 2011e). Measured $\mathrm{CH}_{4}$ oxidation rate at $22^{\circ} \mathrm{C}$ ranged between 14 and $168 \mu \mathrm{g} \mathrm{CH}_{4} \mathrm{gDM}^{-1} \mathrm{~h}^{-1}$ demonstrating a wide variability of the methanotrophic activity. These results are widely comparable with the ones obtained in the study presented here with a $\mathrm{CH}_{4}$ oxidation rate at $30^{\circ} \mathrm{C}$ ranging between 25 and $131 \mu \mathrm{g} \mathrm{CH}_{4} \mathrm{gDM}^{-1} \mathrm{~h}^{-1}$. 


\subsection{Potential inhibitory effect of tracer addition on methane oxidation activity}

The result of the first experiment evaluating the potential inhibitory effect of the presence of HFC134a to the $\mathrm{CH}_{4}$ oxidation activity is displayed in Fig. 2. The $\mathrm{CH}_{4}$ oxidation rates for all the different HFC134a concentrations ( 0 to $140 \mathrm{ppmv}$ ) were almost equal and ranged between 20 and $25 \mu \mathrm{g} \mathrm{CH}_{4} \mathrm{gDM}^{-1} \mathrm{~h}^{-1}$

(Fig. 2). Thus no noticeable influence was found on the performance of $\mathrm{CH}_{4}$ oxidation due to the presence of HFC-134a. These results are also corroborated by the second tracer experiment performed in May 2013 and presented in Table 2. $\mathrm{CH}_{4}$ oxidation rates measured on mixed compost or depth-specific compost at both 30 and $50^{\circ} \mathrm{C}$ did not show any change depending on tracer presence, validating the results achieved in the first test. This means that the performance of the tracer test in full scale in the biocover will not have any influence on the $\mathrm{CH}_{4}$ oxidation performance of the biocover during the tracer release.

\subsection{Single point $\mathrm{CH}_{4}$ oxidation - comparison of the carbon balance and the tracer gas method}

Fig. 3 shows representative vertical gas composition profiles measured at two locations in the Southern and Northern sampling transects (S8 and N8). Gas composition profiles in the biocover indicated $\mathrm{CH}_{4}$ oxidation especially in the lower part of the biocover (100 to $50 \mathrm{~cm}$ below the surface). It is evident that also the lower part contained significant concentrations of oxygen (often 3-5\% or more) from the atmosphere as well as from the fed gas. The presence of $\mathrm{O}_{2}$ at all depths of the cover indicated that $\mathrm{CH}_{4}$ oxidation in the field was not limited by available $\mathrm{O}_{2}$.

$\mathrm{CH}_{4}$ oxidation in the biocover was also demonstrated by the vertical distribution of the ratio between the concentrations of $\mathrm{CH}_{4}$ and $\mathrm{CO}_{2}$ with the concentration of $\mathrm{HFC}-134 a\left(\mathrm{C}_{2} \mathrm{H}_{2} \mathrm{~F}_{4}\right)$ as shown in Fig. 4 (locations S1, S4, S8 and S10 in the Southern transect). The profiles were measured after tracer breakthrough had been reached. Gas concentration profiles represented in Fig. 4 clearly show how $\mathrm{CH}_{4}$ and $\mathrm{CO}_{2}$ concentrations change with depth in the biocover due to methanotrophic activity. The $\mathrm{CH}_{4} / \mathrm{C}_{2} \mathrm{H}_{2} \mathrm{~F}_{4}$ ratio clearly shows a decreasing trend from the bottom to the upper surface of the biocover demonstrating that $\mathrm{CH}_{4}$ is being oxidized during its flow through the biocover pores. At the same time the $\mathrm{CO}_{2} / \mathrm{C}_{2} \mathrm{H}_{2} \mathrm{~F}_{4}$ ratio describe an increasing trend during its flow through the biocover. In this case, the $\mathrm{CO}_{2}$ production from $\mathrm{CH}_{4}$ oxidation is however not the only reason of the ratio variation because compost respiration is also active in the biocover. The latter is clearly shown by the higher mixing ratio of $\mathrm{CO}_{2} / \mathrm{C}_{2} \mathrm{H}_{2} \mathrm{~F}_{4}$ (up to 6000 in the upper 
part of the biocover) in comparison to the $\mathrm{CH}_{4} / \mathrm{C}_{2} \mathrm{H}_{2} \mathrm{~F}_{4}$ ratio (starting from 400 at the lower part of the biocover).

Table 3 compares $\mathrm{CH}_{4}$ oxidation efficiencies and rates obtained by using the carbon mass balance method (as described in section 2.3) and the trace gas method (see section 2.4) obtained from eight single points during two campaigns. Using the carbon mass balance approach, a $\mathrm{CH}_{4}$ oxidation efficiency in the range of 84 to a $100 \%$ was obtained whereas using the tracer gas approach resulted in a slightly higher $\mathrm{CH}_{4}$ oxidation efficiency ranging from 97 to $100 \%$ (Table 3). One of the uncertainties related to the carbon mass balance method is the assumption that the measured $\mathrm{CO}_{2}$ emission is caused solely by $\mathrm{CH}_{4}$ oxidation. However, in reality a part of the emitted $\mathrm{CO}_{2}$ is due to compost respiration. Considering $\mathrm{CO}_{2}$ from compost respiration in the carbon mass balance (Eq. 1-5) will however reduce the $\mathrm{CH}_{4}$ oxidation efficiency further thus not explaining the observed difference between the two methods. Subtracting a surface $\mathrm{CO}_{2}$ flux caused by respiration from the measured $\mathrm{CO}_{2}$ surface flux (Eq. 1) will result in a lower $\mathrm{CH}_{4}$ flux to the bottom of the biocover (Eq. 3) and thus a lower oxidation rate (Eq. 4) and oxidation efficiency (Eq. 5). The $\mathrm{CH}_{4}$ oxidation rates were much higher using the tracer gas balance method giving $\mathrm{CH}_{4}$ oxidation rates between 7 and $124 \mathrm{~g} \mathrm{~m}^{2} \mathrm{~d}^{-1}$ in comparison to the using carbon mass balance, which gave oxidation rates between -0.06 and $40 \mathrm{~g} \mathrm{~m}^{2} \mathrm{~d}^{-1}$. The higher $\mathrm{CH}_{4}$ oxidation rates obtained using the tracer gas mass balance approach is most likely due to fact that $\mathrm{CH}_{4}$ oxidized in the gas distribution layer is included in the oxidation, since it is the ratio between inlet tracer and surface emitted tracer which is calculated (Eq. 6). In the carbon mass balance it is the gas composition in the bottom of the biocover that is the starting point (Eq. 1-5) and in this case, the $\mathrm{CH}_{4}$ that is oxidized in the gas distribution layer (before it enters the compost layer) is not included. Another difference between the two methods is that the assumption of 1D gas flow in the carbon mass balance method, is not necessary for the tracer method. The flow in the methane oxidation layer may not be complete vertical making some additional uncertainty in the carbon mass balance method.

The correlation between the two methods were relatively weak $\left(R^{2}<0.6\right)$, which most likely is caused by inhomogeneities in the biocover system - both in the gas distribution system as well as in the compost layer. The results showed significant spatial variations in $\mathrm{CH}_{4}$ load and $\mathrm{CH}_{4}$ oxidation and also showed a much higher $\mathrm{CH}_{4}$ oxidation capacity in some single points in comparison to the average whole biocover $\mathrm{CH}_{4}$ oxidation rates of $13 \mathrm{~g} \mathrm{~m}^{2} \mathrm{~d}^{-1}$ (see next section). In general, higher $\mathrm{CH}_{4}$ oxidation rates were obtained for single points located in the Southern multi port sampling transect (Fig. 1; S1-S10), which most likely was due 
to the fact that this part of the biocover received a higher $\mathrm{CH}_{4}$ load as it was closer to the un-slotted inlet gas load pipe. In addition to this, a significant part of the $\mathrm{CH}_{4}$ might be oxidized in the gas distribution layer once the gas enters the slotted gas distribution pipes, why the $\mathrm{CH}_{4}$ load to $\mathrm{CH}_{4}$ oxidation layer in the Northern part is lower in comparison to the Southern part. This was supported by the results of a tracer gas experiment, which showed equal distribution of tracer gas to different parts of the biocover by the un-slotted gas distribution pipe and even distributed emissions of tracer gas over the biocover area (Cassini et al., 2017). Combined the results show that both $\mathrm{CH}_{4}$ and tracer gas was efficiently distributed throughout the Southern section of the biocover but that $\mathrm{CH}_{4}$ most likely was oxidized before reaching the Northern part of the biocover, whereas the tracer gas was equally distributed throughout the biocover (both the Southern and the Northern section). In all parts of the biocover, the $\mathrm{CH}_{4}$ oxidation capacity was however higher than the $\mathrm{CH}_{4}$ load resulting in very low surface $\mathrm{CH}_{4}$ emissions.

\subsection{Whole biocover $\mathrm{CH}_{4}$ oxidation based on $\mathrm{CH}_{4}$ load and $\mathrm{CH}_{4}$ surface emission}

As shown in the presentation of the performed surface fluxes (confer Cassini et al., 2017) very low $\mathrm{CH}_{4}$ fluxes were recorded in general varying between negative emissions $\left(-0.006 \mathrm{~mol} \mathrm{~m}^{-2} \mathrm{~d}^{-1}\right)$ indicating atmospheric $\mathrm{CH}_{4}$ uptake to maximum $\mathrm{CH}_{4}$ surface fluxes of about $0.12 \mathrm{~mol} \mathrm{~m}^{-2} \mathrm{~d}^{-1}$. In comparison to $\mathrm{CH}_{4}$ fluxes, much higher $\mathrm{CO}_{2}$ fluxes were recorded indicating significant $\mathrm{CH}_{4}$ oxidation and compost respiration. A few areas with higher $\mathrm{CH}_{4}$ emissions were observed indicating some spatial emission variation. Table 4 presents $\mathrm{CH}_{4}$ oxidation efficiencies and $\mathrm{CH}_{4}$ oxidation rates for the whole biocover system determined based on the $\mathrm{CH}_{4}$ load (inlet $\mathrm{CH}_{4}$ concentrations and gas flow recording) and surface $\mathrm{CH}_{4}$ emissions measurements. Overall, the $\mathrm{CH}_{4}$ oxidation efficiency of the biocover varied between 81 and almost $100 \%$ - in most cases over $94 \%$ - and showed that the pilot plant biocover system installed at AV Miljø Landfill was very efficient in oxidizing the landfill $\mathrm{CH}_{4}$. The $\mathrm{CH}_{4}$ oxidation rate varied between 8 and $18 \mathrm{~g} \mathrm{~m}^{-2} \mathrm{~d}^{-1}$ (Table 4). The average biocover performance was estimated to be around $13 \mathrm{~g} \mathrm{~m}^{2} \mathrm{~d}^{-1}$, which is relatively low in comparison to previous biocover studies (Scheutz et al., 2009). Considering the high $\mathrm{CH}_{4}$ oxidation efficiency it is likely that the biocover was over-dimensioned and had the potential to oxidize a much higher $\mathrm{CH}_{4}$ load if needed (see further below).

The laboratory-measured $\mathrm{CH}_{4}$ oxidation potential as function of temperatures can be used to estimate the whole biocover $\mathrm{CH}_{4}$ oxidation potential (assuming that the $\mathrm{CH}_{4}$ oxidation, which is occurring in the field is not limited by $\mathrm{O}_{2}$ and/or by moisture content). The methane oxidizing layer of the biocover was divided in five 
horizontal layers (20 cm each) and temperature homogeneity assumed for each stratum. Reference temperatures were chosen based on data from probes installed in the biocover soil (as described in Cassini et al., 2017). The maximal $\mathrm{CH}_{4}$ oxidation potential of the biocover was then calculated by considering the methanotrophic oxidation rate measured during the laboratory incubation studies for each reference temperature (results reported in section 3.1 and data shown in Table 1). The specific $\mathrm{CH}_{4}$ oxidation potential was calculated in this way to be around $300 \mathrm{~g} \mathrm{CH}_{4} \mathrm{~m}^{-2} \mathrm{~d}^{-1}$ (assuming no $\mathrm{O}_{2}$ or moisture limitation). If the higher $\mathrm{CH}_{4}$ oxidation rates obtained in the laboratory experiments testing the potential inhibition of $\mathrm{HFC}-134 \mathrm{a}$ (Table 2) were used instead, a specific $\mathrm{CH}_{4}$ oxidation potential higher than $300 \mathrm{~g} \mathrm{CH}_{4} \mathrm{~m}^{-2} \mathrm{~d}^{-1}$ would be obtained. The results of the field measurement campaigns showed significantly different results. The average specific biocover performance was as previously mentioned calculated to be between 8 and $18 \mathrm{~g}$ $\mathrm{CH}_{4} \mathrm{~m}^{-2} \mathrm{~d}^{-1}$, but peaks of noticeably higher values where measured in different points of the biocover from time to time (up to124 $\mathrm{g} \mathrm{CH}_{4} \mathrm{~m}^{2} \mathrm{~d}^{-1}$ as reported in the previous section). It is reasonable to conclude that the maximal $\mathrm{CH}_{4}$ oxidation potential of the biocover is several times higher than the average performance calculated based on the whole-biocover measuring campaigns. This is both shown from theoretical calculations (based on lab experiments) and from field (point flux chambers) results. The reason for the low specific biocover performance of 8-18 $\mathrm{gCH}_{4} \mathrm{~m}^{-2} \mathrm{~d}^{-1}$ is that the load of $\mathrm{CH}_{4}$ injected in the biocover was much lower than the biocover $\mathrm{CH}_{4}$ oxidation potential, which could be realized with a higher $\mathrm{CH}_{4}$ load. We do not find it likely that the $\mathrm{CH}_{4}$ oxidation occurring in the biocover was limited by $\mathrm{O}_{2}$ or by compost moisture as $\mathrm{O}_{2}$ was present at all depths of the biocover and as the volumetric compost moisture content $\left(\mathrm{m}^{3} \cdot \mathrm{m}^{-3}\right)$ varied between about 0.2 and 0.5 (Cassini et al., 2017), which is a sufficient moisture content for $\mathrm{CH}_{4}$ oxidation (neither too low nor too high) (Scheutz et al., 2009). Mor et al. (2006) obtained maximum $\mathrm{CH}_{4}$ oxidation rates in compost at moisture contents ranging from $45 \%$ to $110 \%$ (dry weight basis). A volumetric compost moisture content of 0.2 to 0.5 corresponds to moisture contents of 40 to $100 \%$ (dry weight basis) (when assuming a compost bulk density of $500 \mathrm{~kg} \mathrm{~m}^{-3}$ ), which is within the moisture range for optimal $\mathrm{CH}_{4}$ oxidation reported by Mor et al. (2006) and thus indicating that moisture was most likely not a limiting factor for $\mathrm{CH}_{4}$ oxidation in the biocover.

However, high $\mathrm{CH}_{4}$ oxidation efficiencies in the range of $81-99 \%$ were measured and the biocover was demonstrated to be efficient during the whole study period. Reasons for the substantial efficiency of the biocover were the optimal distribution of $\mathrm{O}_{2}$ at every depth of the biocover, the relatively low $\mathrm{CH}_{4}$ load to the 
biocover, the efficient and homogeneous gas distribution throughout the Southern section of the biocover perpendicular to the gas inlet, and significant $\mathrm{CH}_{4}$ oxidation in the gas distribution layer. High $\mathrm{CH}_{4}$ oxidation efficiencies were even found during winter time with low ambient temperatures, which in previous studies brought the methanotrophic activity to stagnation (Stern at al., 2007). During winter time when the ambient air temperature was between -5 and $+5^{\circ} \mathrm{C}$, the temperature in the biocover remained high and closed to the optimum temperature (around $55^{\circ} \mathrm{C}$ ) as measured in the laboratory incubation experiment. This obviously had a positive effect on the methanotrophs resulting in high $\mathrm{CH}_{4}$ oxidation rates and efficiencies. Previous studies reported optimal temperature for methanotrophic bacteria ranging between $25-30^{\circ} \mathrm{C}$ (Scheutz et al., 2009) and $30^{\circ}-40^{\circ} \mathrm{C}$ (Streese and Stegmann, 2003). Gas profiles (Fig. 3) showed that the maximal $\mathrm{CH}_{4}$ oxidation activity was measured between $-40 \mathrm{~cm}$ and $-90 \mathrm{~cm}$, which was also where optimal temperatures were recorded and where also $\mathrm{O}_{2}$ was present.

\subsection{Evaluation of compost respiration by biocover carbon balance}

The carbon mass balance application as shown in Table 4 proved that the total emitted carbon (sum of $\mathrm{C}-\mathrm{CH}_{4}$ and $\mathrm{C}-\mathrm{CO}_{2}$ ) from the biocover surface was considerably higher than the carbon load into the system. Considering the $\mathrm{CO}_{2}$ load in the inlet (about 4-6 $\mathrm{kg} \mathrm{C} \mathrm{d}^{-1}$ ) and the $\mathrm{CO}_{2}$ generated from methanotrophic activity (about 4-8 $\mathrm{kg} \mathrm{C} \mathrm{d}^{-1}$ ), the additional $\mathrm{CO}_{2}$ must be produced from respiration of the compost (about 0-76 kg C d${ }^{-1}$, when subtracting the carbon in the $\mathrm{CO}_{2}$ in the inlet gas and the carbon in the $\mathrm{CO}_{2}$ generated from $\mathrm{CH}_{4}$ oxidation from the carbon in the total $\mathrm{CO}_{2}$ emission) (Table 4). The average estimated carbon flux caused by compost respiration activity based on field measurements for the year 2013 steadily decreased from a value of $76 \mathrm{~kg} \mathrm{C} \mathrm{d}^{-1}$ in March to a value of $14 \mathrm{~kg} \mathrm{C} \mathrm{d}^{-1}$ in October (Table 4). For the last campaigns in 2014, the estimated carbon flux caused by compost respiration activity had further decreased to a very low level (the estimated values are actually below zero, which probably is due to uncertainties in the measured inlet load and surface emissions). Similar decrease of the respiration with time was observed at the Klintholm Biocover (Scheutz et al., 2014).

The respiration potential of the biocover compost for the early period (January - May 2013) was estimated using the laboratory data previously presented. The $\mathrm{CH}_{4}$ oxidation layer was divided into 5 horizontal parallel layers and for each layer a representative temperature was assumed. Data collected from temperature probes (confer Cassini et al., 2017) installed at different depths in the biocover $\mathrm{CH}_{4}$ oxidation 
layer were analysed. A flexible temperature range was adopted based on the corresponding probe data to simulate the changing seasonal temperature trend. Respiration rates determined by the laboratory experiments were used (as presented in section 3.1). A maximum and minimum compost respiration potential was calculated by associating a respiration rate range to the temperature range. The calculated $\mathrm{CO}_{2}$ generation rates showed plausible results. The calculated respiration range was $10-33 \mathrm{~kg} \mathrm{C} \mathrm{d}^{-1}$, which is in the same range as the previously reported average estimated carbon flux contributed by compost respiration activity based on field measurements; $12-26 \mathrm{~kg} \mathrm{C} \mathrm{d}^{-1}$ - omitting the exceptional high values estimated for the $2^{\text {nd }}$ and the $3^{\text {rd }}$ measuring campaigns (see Table 4). For these two campaigns the field results showed double of the maximal load calculated with the laboratory studies. The use of kriging interpolation in case of considerably higher emission hot spots (6-8 times the average value) can give over estimation of the integrated carbon flux and may be the reason for the deviation between field measurements and laboratory result based estimations for the $2^{\text {nd }}$ and the $3^{\text {rd }}$ measuring campaign.

\section{Conclusion and Perspectives}

Laboratory batch incubation experiments performed by use of compost sampled from the $\mathrm{CH}_{4}$ oxidation layer of the biocover system showed a high $\mathrm{CH}_{4}$ oxidation activity in the whole range of temperatures $\left(4\right.$ to $\left.70{ }^{\circ} \mathrm{C}\right)$ observed in the biocover system. The experiment showed a temperature optimum for the $\mathrm{CH}_{4}$ oxidation process of $55^{\circ} \mathrm{C}$, which is much higher than temperature optimum measured for landfill cover soils. Respiration tests performed in the same temperature range showed the highest respiration activity for the highest temperature tested $\left(70^{\circ} \mathrm{C}\right)$. The test revealed that the biocover will emit considerable amounts of $\mathrm{CO}_{2}$ as a result of compost respiration.

Laboratory experiments performed with and without the addition of the used tracer gas, HFC-134a, showed no inhibitory effect from the tracer gas in a relevant concentration range (up to $160 \mathrm{ppmv}$ ) on the $\mathrm{CH}_{4}$ oxidation activity in the compost layer. This means that the tracer gas can safely be added to the inlet gas without affecting the ongoing $\mathrm{CH}_{4}$ oxidation process.

$\mathrm{CH}_{4}$ balances of the biocover established by measuring the $\mathrm{CH}_{4}$ load to the biocover system and the emitted $\mathrm{CH}_{4}$ through the biocover surface (through integration of flux measurements performed in over fifty points on the biocover surface) showed that the system had a very high $\mathrm{CH}_{4}$ oxidation efficiency independent 
of the time of the year - in most cases close to $100 \%$ efficiency. The active $\mathrm{CH}_{4}$ oxidation process was further documented by point measurements of the $\mathrm{CH}_{4}$ oxidation capacity using a carbon balance approach and a new-developed method using information about $\mathrm{CH}_{4}$ and tracer gas fluxes. The tracer-based method gave more realistic $\mathrm{CH}_{4}$ oxidation efficiencies in comparison to the carbon balance method, and was proven to be an efficient method for quantifying the $\mathrm{CH}_{4}$ oxidation efficiency of a pipe-loaded biocover system, where the tracer gas easily can be added to the gas inlet.

The $\mathrm{CH}_{4}$ balances of the biocover showed that the $\mathrm{CH}_{4}$ load to the biocover system was in general lower than anticipated and resulted in relative low methane oxidation rates - on an absolute scale between 8 and $18 \mathrm{~g} \mathrm{CH}_{4} \mathrm{~m}^{-2} \mathrm{~d}^{-1}$. Extrapolating the laboratory determined $\mathrm{CH}_{4}$ oxidation rates assuming no $\mathrm{O}_{2}$ limitation and using oxidation rates corresponding to the temperatures measured in the biocover, $\mathrm{a} \mathrm{CH}_{4}$ oxidation potential of $300 \mathrm{~g} \mathrm{CH}_{4} \mathrm{~m}^{-2} \mathrm{~d}^{-1}$ was calculated; much higher than the actual $\mathrm{CH}_{4}$ oxidation rate, which most likely was limited by the low $\mathrm{CH}_{4}$ load to the system.

At many landfills a significant part of the generated landfill gas may emit through leachate wells. At such landfills, the $\mathrm{CH}_{4}$ emission may efficiently be mitigated by a biocover system similar to the pilot-scale system implemented at the AV Miljø Landfill. However, additional studies need to be performed to construct the optimal gas distribution system - the distance between the gas distribution pipes can maybe be increased to reduce costs. The $\mathrm{CH}_{4}$ load to the biocover system could be significantly increased to evaluate the in-field capacity of the biocover system.

\section{Acknowledgments}

This research was funded by the AV Miljø disposal site and Technical University of Denmark. We would like to acknowledge Hans Henrik Jørgensen Halvbjørn, Monika Margrethe Skadborg, and Rune Skovsø Møller for calculation of whole biocover $\mathrm{CH}_{4}$ oxidation efficiencies. We would like to acknowledge Zishen Mou for assisting with the field work, and Torben Dolin for his contributions to the graphical work.

\section{References}


Andersen, J.K., Boldrin, A., Samuelsson, J., Christensen, T.H., Scheutz, C., 2010. Quantification of GHG emissions from windrow composting of garden waste. Journal of Environmental Quality, 39, 713-724.

Bogner, J., Pipatti, R., Hashimoto, S., Diaz, C., Mareckova, K., Diaz, L., Kjeldsen, P., Monni, S., Faaij, A., Qingxian, G., Tianzhu, Z., Mohammed, A.A., Sutamihardja, R.T.M., Gregory, R., 2008. Mitigation of global greenhouse gas emissions from waste: conclusions and strategies from the intergovernmental panel on climate change (IPCC) fourth assessment report. Working group III (Mitigation). Waste Manage. Res. 26 (1), 11-32.

Cassini F., Skov, B.H., Mou, Z., Scheutz, C., Kjeldsen, P., 2017. Mitigation of methane emissions in a pilotscale biocover system at the AV Miljø Landfill, Denmark: 1. System design and gas distribution. Waste Management, $\mathrm{xx}, \mathrm{xx}-\mathrm{xx}$.

Christophersen, M., Holst, H., Chanton, J., Kjeldsen, P., 2001a. Lateral gas transport in soil adjacent to an old landfill: Factors governing emission and methane oxidation. Waste Management and Research. 19, $595-612$.

Einola, J. -K. M., Sormunen, K. M., Rintala, J. A., 2008. Methane oxidation in a boreal climate in an experimental landfill cover composed from mechanically-biologically treated waste. Science of the Total Environment, 407(1), 67-83.

Einola, J., Sormunen, K., Lensu, A., Leiskallio, A., Ettala, M., Rintala, J., 2009. Methane oxidation at a surface-sealed boreal landfill. Waste Manag. 29 (7), 2105-2120.

Mor, S., De Visscher, A., Ravindra, K., Dahiya, R.P., Chandra, A., Van Cleemput, O. 2006. Induction of enhanced methane oxidation in compost: Temperature and moisture response. Waste Management 26, 381-388.

Pedersen, G. B., Scheutz, C., and Kjeldsen, P., 2011. Availability and properties of materials for the Fakse Landfill biocover. Waste Management , 31(5), 884-894.

Philopoulos, A., Felske, C., McCartney, D. 2008., Field-scale treatment of landfill gas with a passive methane oxidizing biofilter . Journal of Environmental Engineering and Science, 7(5), 531-542.

Scheutz, C., Pedersen, R.B., Petersen, P.H., Jørgensen, J.H.B., Ucendo, I.M.B., Mønster, J.G.,Samuelsson, J. \& Kjeldsen, P., 2014. Mitigation of methane emission from an old unlined landfill in Klintholm, Denmark using a passive biocover system, Waste Management, 34, 1179-1190. 
Scheutz, C., Fredenslund, A. M., Chanton, J., Pedersen, G. B., Kjeldsen, P., 2011a. Mitigation of methane emission from Fakse landfill using a biowindow system. Waste Management, 31(5), 1018-1028.

Scheutz, C., Samuelsson, J., Fredenslund, A. M., Kjeldsen, P., 2011b. Quantification of multiple methane emission sources at landfills using a double tracer technique. Waste Management, 31(5), 1009-1017.

Scheutz, C., Fredenslund, A. M., Nedenskov, J., Samuelsson, J., and Kjeldsen, P., 2011c. Gas production, composition and emission at a modern disposal site receiving waste with a low-organic content. Waste Management , 31(5), 946-955.

Scheutz, C., Meroño, A.R., Pedersen, R.B., Kjeldsen , P., 2011d. Temperatures in compost landfill covers as result of methane oxidation and compost respiration. In: Proceedings Sardinia 2011, Thirteenth International Waste Management and Landfill Symposium, S. Margherita di Pula, Cagliari, Italy; 3 - 7 October 2011. 2011 by CISA, Environmental Sanitary Engineering Centre, Italy.

Scheutz, C., Pedicone, A., Pedersen, G. B., and Kjeldsen, P., 2011e. Evaluation of respiration in compost landfill biocovers intended for methane oxidation. Waste Management, 31(5), 895-902.

Scheutz, C.,. Bogner, J., De Visscher, A., Gebert, J., Hilger, H., Huber-Humer, M., Kjeldsen, P., and Spokas, K., 2009. Processes and technologies for mitigation of landfill gas emissions by microbial methane oxidation. Waste Management \& Research, 27(5), 409-455.

Stern, J.C., Chanton, J., Abichou, T., Powelson, D., Yuan, L., Escoriza, S., Bogner, J., 2007. Use of a biologically active cover to reduce landfill methane emissions and enhance methane oxidation. Waste Management, 27, 1248-1258.

Streese J., Stegman, R., 2003. Microbial oxidation of $\mathrm{CH}_{4}$ from old landfills in biofilters. Waste Management, 23, 573-580. 


\section{Tables}

\section{Table 1}

Results of methane oxidation and respiration experiments performed at different temperatures on the composite compost sample from November 2012 at location T2. The compost moisture content was $0.4 \mathrm{~g} \mathrm{~g}$ $\mathrm{DM}^{-1}$ and the initial $\mathrm{CH}_{4}$ concentration was $14 \%$ vol. All rates are in the unit $\mu \mathrm{g} \mathrm{g} \mathrm{DM}{ }^{-1} \mathrm{~h}^{-1}$.

\begin{tabular}{|c|c|c|c|c|c|}
\hline \multirow[b]{2}{*}{$\begin{array}{l}\text { Temperature } \\
\left({ }^{\circ} \mathrm{C}\right)\end{array}$} & \multicolumn{3}{|c|}{ Methane oxidation experiment } & \multicolumn{2}{|c|}{ Respiration experiment } \\
\hline & $\mathrm{CH}_{4}$ oxidation & $\mathrm{O}_{2}$ consumption & $\begin{array}{l}\mathrm{CO}_{2} \\
\text { production }\end{array}$ & $\mathrm{O}_{2}$ consumption & $\mathrm{CO}_{2}$ production \\
\hline 4 & $0.13^{\mathrm{a}}$ & $4.7^{\mathrm{a}}$ & $2.1^{\mathrm{a}}$ & $1.1 \pm 0.23$ & $0.52 \pm 0.05$ \\
\hline 10 & $0.04^{a}$ & $3.4^{\mathrm{a}}$ & $2.8^{\mathrm{a}}$ & $1.4 \pm 0.28$ & $1.0 \pm 0.04$ \\
\hline 15 & $1.8 \pm 0.02$ & $14.2 \pm 0.1$ & $4.5 \pm 0.7$ & $2.8 \pm 0.29$ & $2.8 \pm 0.38$ \\
\hline 20 & $6.0 \pm 0.5$ & $27 \pm 2.0$ & $15 \pm 1.1$ & $4.5 \pm 0.72$ & $4.2 \pm 0.30$ \\
\hline 30 & $25 \pm 1.5$ & $76 \pm 19$ & $51 \pm 8.6$ & $5.4 \pm 0.26$ & $5.6 \pm 0.19$ \\
\hline 40 & $65^{a}$ & $210^{\mathrm{a}}$ & $170^{\mathrm{a}}$ & $22 \pm 8.0$ & $26 \pm 9.0$ \\
\hline 55 & $73 \pm 4.6$ & $290 \pm 8.7$ & $230 \pm 18$ & $39 \pm 0.57$ & $43 \pm 1.1$ \\
\hline 70 & $2.0 \pm 0.11$ & $84 \pm 8.7$ & $91 \pm 17$ & $65 \pm 0.16$ & $73 \pm 1.3$ \\
\hline
\end{tabular}

a: The batches for the methane oxidation experiments at 4,10 and $40{ }^{\circ} \mathrm{C}$ were not duplicated. 


\section{Table 2}

Methane oxidation rates determined in batch tests for depth specific compost samples (sampled at $-40 \mathrm{~cm}$ depth) and for composite compost samples (obtained by mixing equal amounts of compost sampled at $-20 \mathrm{~cm},-40 \mathrm{~cm}$ and $-60 \mathrm{~cm}$ depth). First experimental round made on depth specific sample $(-40 \mathrm{~cm})$ at $\mathrm{HFC}-134^{\circ}$ concentration in the range of $0-140 \mathrm{ppmv}$ at $50^{\circ} \mathrm{C}$. Second experimental round made both on composite and depth specific sample with either no addition of HFC-134 ${ }^{\circ}$ or HFC-134 ${ }^{\circ}$ addition at fixed concentration (160 ppmv) and at two temperatures $\left(30^{\circ} \mathrm{C}\right.$ and $\left.50^{\circ} \mathrm{C}\right)$. The compost moisture content was $0.4 \mathrm{~g} \mathrm{~g} \mathrm{DM}^{-1}$. All rates are in the unit $\mu \mathrm{g} \mathrm{CH}_{4} \mathrm{~g} \mathrm{DM}^{-1} \mathrm{~h}^{-1}$.

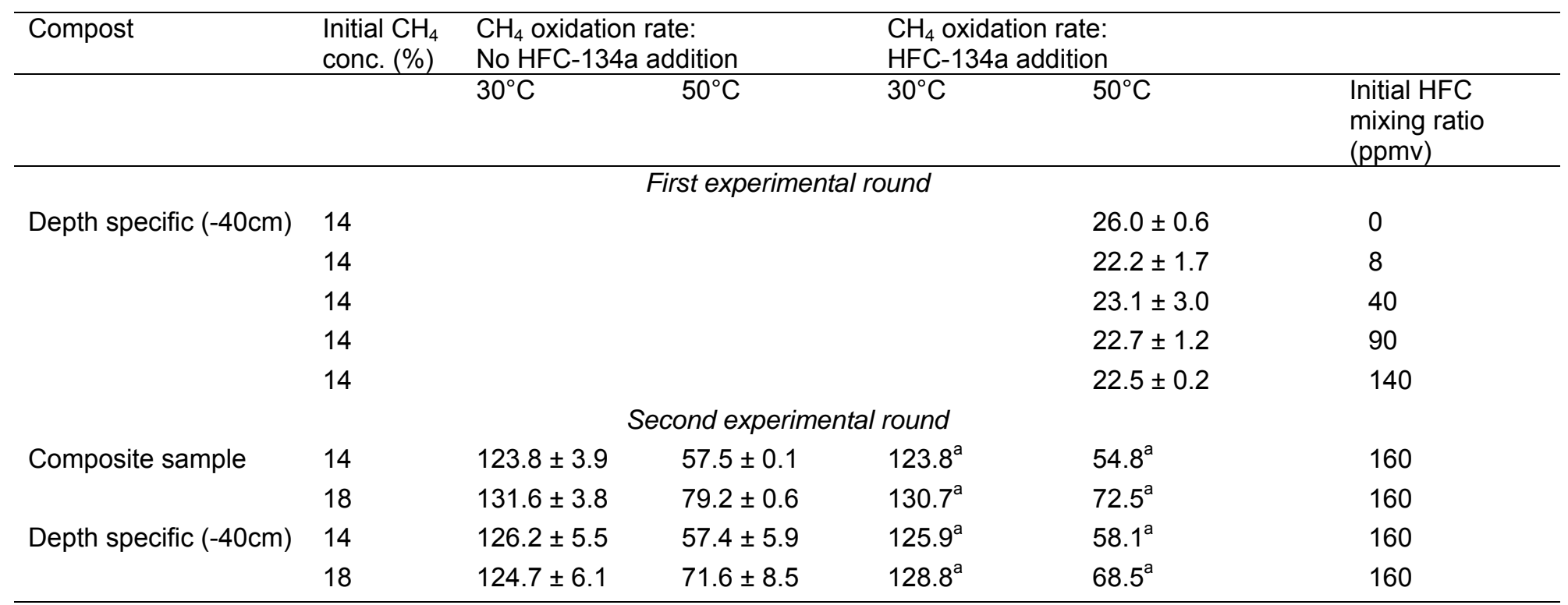

a: The batches for the methane oxidation experiments with HFC-134 ${ }^{\circ}$ addition in the second experimental round were not duplicated 


\section{Table 3}

Comparison of $\mathrm{CH}_{4}$ oxidation efficiencies and $\mathrm{CH}_{4}$ oxidation rates obtained using two different methods; the carbon mass balance (CMB) method and the tracer mass balance (TMB) method.

\begin{tabular}{|c|c|c|c|c|c|}
\hline \multirow[t]{2}{*}{$\begin{array}{l}\text { Measure- } \\
\text { ment point }\end{array}$} & \multirow[t]{2}{*}{ Date } & \multicolumn{2}{|c|}{$\begin{array}{c}\mathrm{CH}_{4} \text { Oxidation Efficiency } \\
(\%)\end{array}$} & \multicolumn{2}{|c|}{$\begin{array}{l}\mathrm{CH}_{4} \text { Oxidation Rate } \\
\left(\mathrm{g} \mathrm{CH}_{4} \cdot \mathrm{m}^{-2} \cdot \mathrm{d}^{-1}\right)\end{array}$} \\
\hline & & CMB & TMB & CMB & TMB \\
\hline \multirow{2}{*}{ S1 } & 08.12 .12 & 94.4 & 98.7 & 27.38 & 124.18 \\
\hline & 24.05 .13 & 97.3 & 98.6 & 39.91 & 85.04 \\
\hline \multirow{2}{*}{ S7-S8 } & 08.12 .12 & 91.1 & 98.9 & 8.71 & 75.19 \\
\hline & 24.05 .13 & 97.2 & 98.3 & 14.43 & 37.07 \\
\hline \multirow[t]{2}{*}{ S10 } & 08.12 .12 & 96.2 & 98.7 & 23.55 & 68.86 \\
\hline & 24.05 .13 & 97.7 & 98.7 & 4.29 & 7.41 \\
\hline \multirow{2}{*}{ N1 } & 08.12 .12 & 80.5 & - & 0.15 & - \\
\hline & 24.05 .13 & 65.0 & 97.4 & 1.37 & 54.46 \\
\hline \multirow{2}{*}{ N7-N8 } & 08.12 .12 & $100.0^{*}$ & - & -0.06 & - \\
\hline & 24.05 .13 & 67.8 & 98.2 & 1.55 & 47.02 \\
\hline \multirow{2}{*}{ N10 } & 08.12 .12 & $100.0^{*}$ & - & -0.04 & - \\
\hline & 24.05 .13 & 56.3 & 98.0 & 0.37 & 22.57 \\
\hline
\end{tabular}

- not analyzed; *: negative $\mathrm{CH}_{4}$ emissions were measured indicating that the biocover at these points take up atmospheric $\mathrm{CH}_{4}$ in addition to the landfill gas $\mathrm{CH}_{4}$. As a result the $\mathrm{CH}_{4}$ oxidation efficiency has been set to $100 \%$. 
Table 4

Overview of whole biocover $\mathrm{CH}_{4}$ oxidation efficiencies and $\mathrm{CH}_{4}$ oxidation rates obtained during nine measuring campaigns performed from January 2013 to March 2014.

\begin{tabular}{|c|c|c|c|c|c|c|c|c|}
\hline \multirow{2}{*}{ Date } & \multicolumn{2}{|c|}{ Inlet load } & \multicolumn{2}{|c|}{ Total surface emission } & \multicolumn{2}{|c|}{$\mathrm{CH}_{4}$ oxidation rate } & \multirow{2}{*}{$\begin{array}{c}\mathrm{CH}_{4} \text { oxida- } \\
\text { tion } \\
\text { efficiency } \\
\%\end{array}$} & \multirow{2}{*}{$\begin{array}{c}\mathrm{CO}_{2} \text { from } \\
\text { compost } \\
\text { respiration* } \\
\text { g C-CO }_{2} \mathrm{~d}^{-1}\end{array}$} \\
\hline & $\mathrm{g} \mathrm{C}-\mathrm{CH}_{4} \mathrm{~d}^{-1}$ & $\mathrm{~g} \mathrm{C}^{-\mathrm{CO}_{2} \mathrm{~d}^{-1}}$ & $\mathrm{~g} \mathrm{C}^{-} \mathrm{CH}_{4} \mathrm{~d}^{-1}$ & $\mathrm{~g} \mathrm{C}-\mathrm{CO}_{2} \mathrm{~d}^{-1}$ & $\mathrm{~g} \mathrm{C}-\mathrm{CH}_{4}$ & $\mathrm{~g} \mathrm{CH}_{4} \mathrm{~m}^{2} \mathrm{~d}^{-1}$ & & \\
\hline 25.01 .13 & 6,930 & 6,121 & 19 & 25,007 & 6,911 & 18.3 & $>99$ & 11,975 \\
\hline 08.03 .13 & 7,732 & 5,370 & 332 & 88,386 & 7,516 & 15.0 & 96 & 75,500 \\
\hline 11.04 .13 & 8,066 & 4,537 & 1,541 & 77,623 & 6,526 & 13.0 & 81 & 66,560 \\
\hline 21.04 .13 & 7,020 & 6,265 & 35 & 36,277 & 6,985 & 14.0 & $>99$ & 23,027 \\
\hline 02.05 .13 & 6,396 & 7,242 & 30 & 39,489 & 6,366 & 12.7 & $>99$ & 25,881 \\
\hline 24.05 .13 & 4,046 & 3,760 & 246 & 28,219 & 3,800 & 7.6 & 94 & 20,659 \\
\hline 25.10 .13 & 4,327 & 3,856 & 42 & 22,050 & 4,285 & 8.6 & $>99$ & 13,909 \\
\hline 02.02 .14 & 5,917 & 5,238 & 315 & 11,024 & 5,602 & 11.2 & 95 & 0,184 \\
\hline 29.03 .14 & 6,841 & 6,081 & 17 & 8,266 & 6,824 & 13.6 & $>99$ & $-4,639$ \\
\hline
\end{tabular}

${ }^{*} \mathrm{CO}_{2}$ from compost respiration $=$ Total $\mathrm{CO}_{2}$ surface emission - Inlet $\mathrm{CO}_{2}$ flux $-\mathrm{CO}_{2}$ generated from $\mathrm{CH}_{4}$ oxidized 
Figures

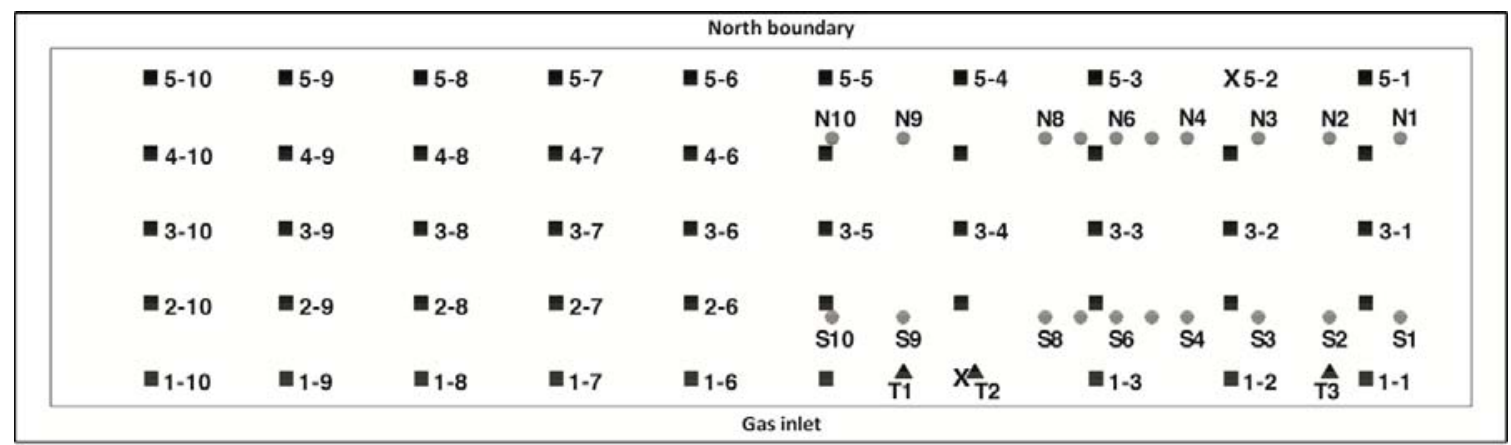

nux chamber locations (10x5) - Multi probe sampling system (10x2)

$X$ Flux chamber location and compost sampling site $\quad \Delta$ Temperature and moisture probes

Fig. 1. Map of the biocover with indications of locations of flux chamber measurements, the multi probe sampling locations, the temperature/moisture probes and compost sampling sites.

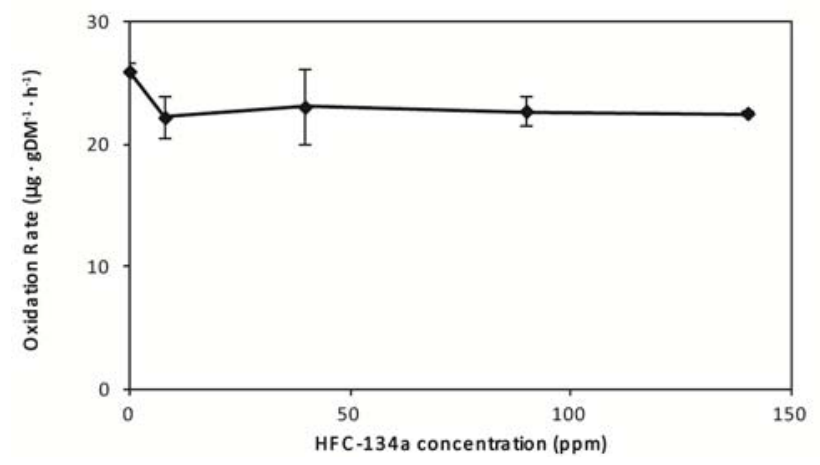

Fig. 2. Methane oxidation rates determined in batch incubation tests shown as a function of initial tracer gas (HFC-134a) concentrations in the batches (0 to $140 \mathrm{ppmv}$ ). 


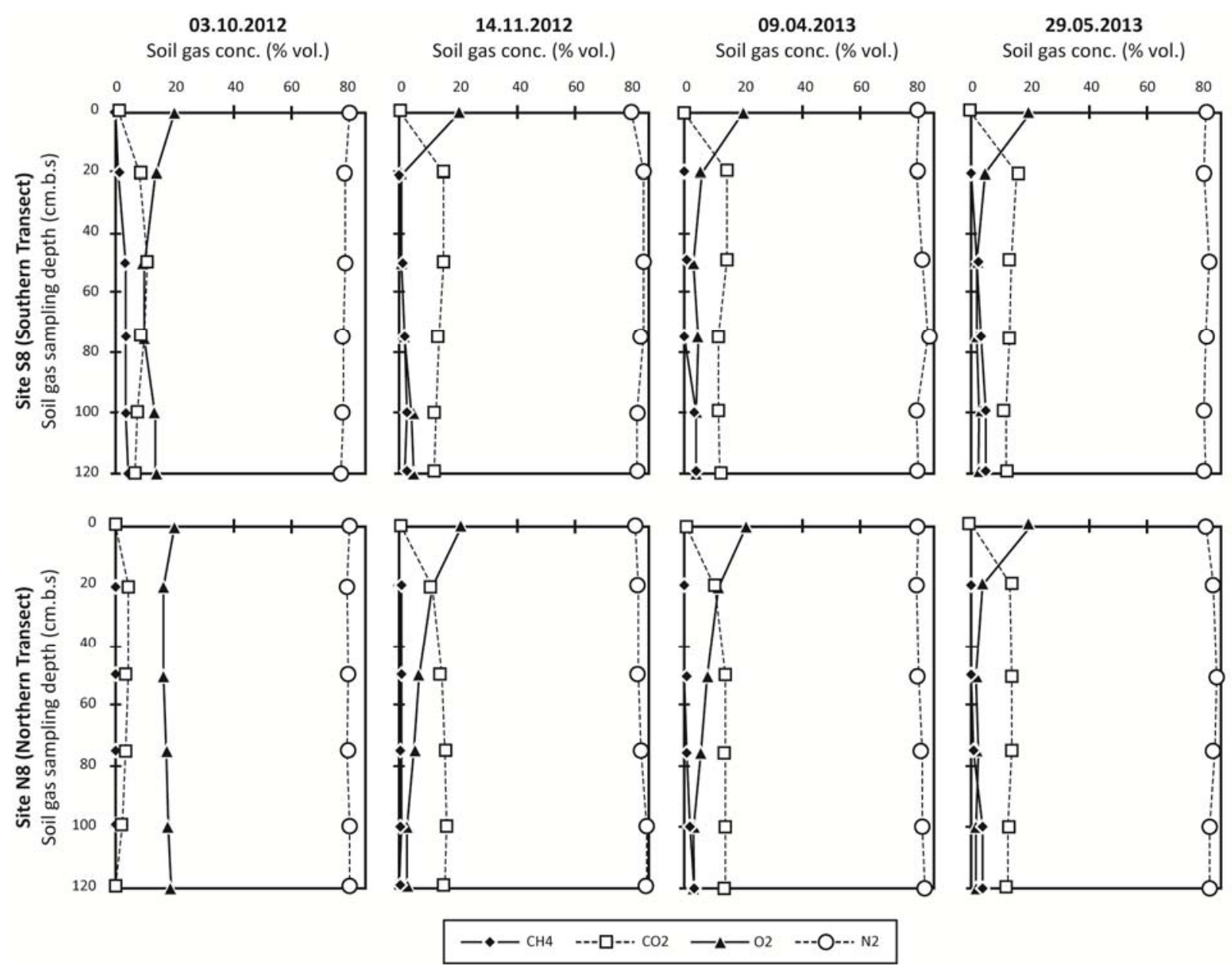

Fig. 3. Vertical gas concentration profiles for $\mathrm{CH}_{4}, \mathrm{CO}_{2}, \mathrm{O}_{2}$ and $\mathrm{N}_{2}$ at two selected locations (S8 and N8) and times (October $3^{\text {th }}, 2012$, November $14^{\text {th }}, 2012$, April $9^{\text {th }}, 2013$ and May $29^{\text {th }}, 2013$ ). 


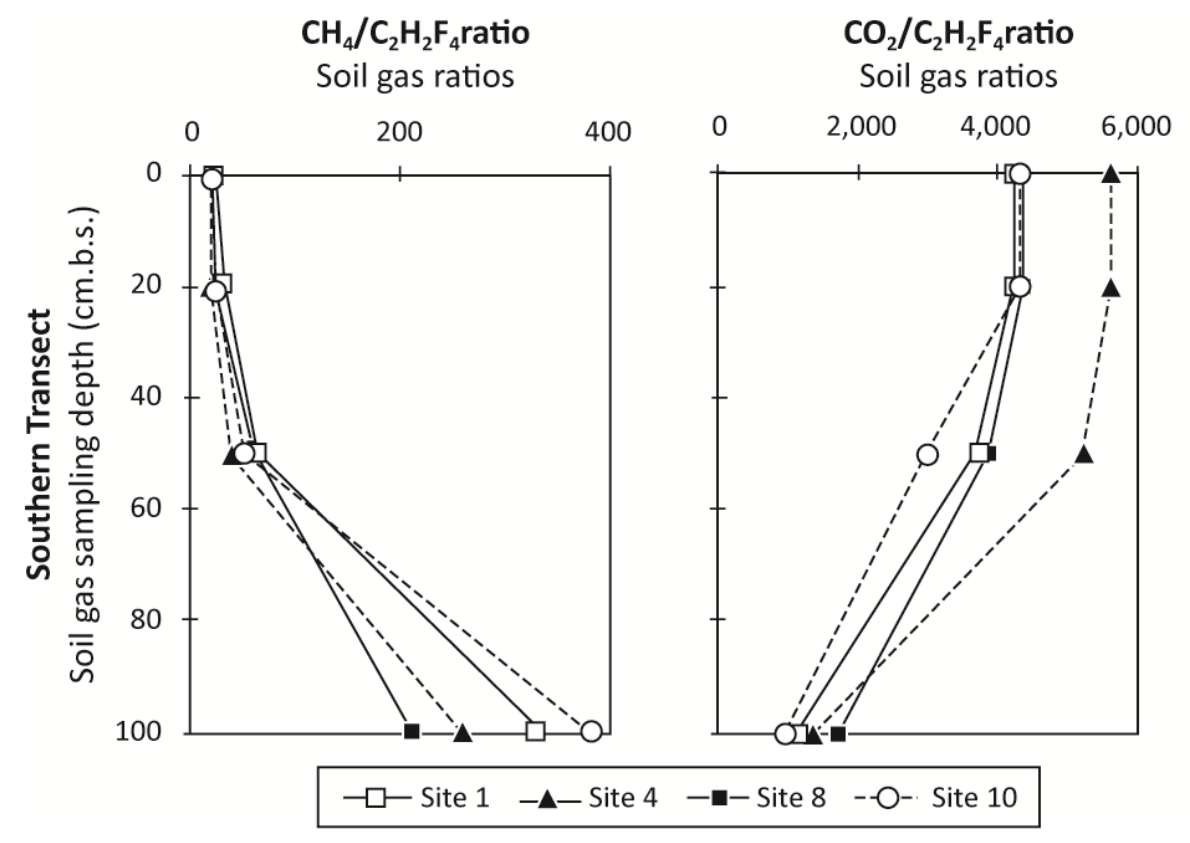

Fig. 4. Vertical gas concentration profiles of the ratios $\mathrm{CH}_{4} / \mathrm{C}_{2} \mathrm{H}_{2} \mathrm{~F}_{4}$ and $\mathrm{CO}_{2} / \mathrm{C}_{2} \mathrm{H}_{2} \mathrm{~F}_{4}$ at four selected locations in the Southern transect $\left(S 1, S 4, S 8\right.$, and S10) as measured on December $8^{\text {th }}, 2012$. Ratios were calculated based on mixing ratios given in ppmv of the individual gases. 